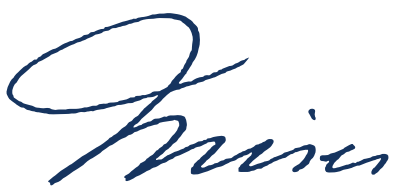

\title{
An Austrian Take on ESG
}

\section{Henrique Schneider I (D) 0000-0002-0428-8967}

Swiss Federation of Small and Medium Enterprises - Schwarztorstrasse - Switzerland

\begin{abstract}
This paper analyzes the contemporary debate about ESG - Environment, Social, Governance - using economic insights from Austrian Economics; particularly, on entrepreneurship, agency, and information asymmetry. These insights contrast to similar concepts in "mainstream" economics, suggesting that the Austrian insight goes beyond them, first by stressing effectiveness in addition to efficiency, institutions, and law-likeliness. When applied to ESG, the Austrian insight portrays it as a special case of the socialist economic calculation debate causing misalignments between inter- and intrafirm goals and agency problems, besides suffering from severe flaws in its conceptualization methodology. Relying on entrepreneurship, however, could make ESG work. Thus, this paper applies Austrian economics to contemporary debates claiming that its insights provide a unique perspective while updating its research program.
\end{abstract}

Keywords: ESG; Socialist Calculation Debate, Agency, Entrepreneurship, Information Asymmetry.

\footnotetext{
${ }^{\text {I } H e n r i q u e ~ S c h n e i d e r ~ g r a d u o u-s e ~ e m ~ E c o n o m i a ~ n a ~ S u i ́ c ̧ a, ~ A l e m a n h a, ~ A ́ u s t r i a, ~ E U A ~ e ~ C h i n a . ~ E l e ~ e c o n o m i s t a-c h e f e ~ d a ~}$ Associação Comercial Suíça SGV, em Berna, na Suíça. É articulista na imprensa diária e em publicações científicas sobre microeconomia, sistema monetário e inovação. Seus livros mais recentes são "Uber: Innovation in Society" e "Creative Destruction and the Sharing Economy". E-mail: hschneider@gmx.ch.
} 


\section{Una Perspectiva Austriaca del ESG}

Resumen: Este artículo analiza el debate contemporáneo sobre ESG (Environment, Social, Governance) utilizando las ideas económicas de la escuela austriaca de economía; en particular, las teorías sobre el espíritu empresarial, la agencia y la asimetría de la información. Estas ideas se contrastan con conceptos similares de la economía "dominante", que sugiere que la visión austriaca va más allá, en primer lugar, al hacer hincapié en la eficacia, además de la eficiencia, y en las instituciones, además de la legalidad. Cuando se aplica al ESG, la visión austriaca retrata el ESG como un caso especial del debate socialista, o de cálculo económico. El ESG provoca desajustes entre los objetivos inter- e infraempresariales, exacerba los problemas de agencia y padece de graves defectos tanto en su conceptualización como en su metodología. Sin embargo, apoyarse en el espíritu empresarial podría hacer que la ESG funcionara. Así pues, este artículo aplica la economía austriaca a los debates contemporáneos, afirmando que sus ideas proporcionan una perspectiva única, pero al mismo tiempo actualizando su programa de investigación.

Palabras clave: ESG, Debate sobre el cálculo económico en socialismo, Agencia, Iniciativa empresarial, Plan de negocio.

\section{Uma perspectiva austríaca do ESG}

Resumo: Esse artigo analisa o debate contemporâneo sobre ESG (Environment, Social, Governance), utilizando as ideias econômicas da Escola Austríaca de Economia; em particular, as teorias sobre empreendedorismo, agência e assimetria de informação. Essas ideias contrastam com conceitos similares da economia "dominante", sugerindo que a visão austríaca vai além, em primeiro lugar, do foco em eficácia, além da eficiência e nas instituições, além da legalidade. Quando aplicado ao ESG, a visão austríaca o retrata como um caso específico do debate socialista, ou do cálculo econômico. O ESG provoca desajustes entre os objetivos inter e infraempresariais, exacerba os problemas de agência e padece de graves defeitos em termos de conceitualização e metodologia. No entanto, apoiar-se no empreendedorismo poderia fazer o ESG funcionar. Assim, esse artigo aplica a economia austríaca aos debates contemporâneos, afirmando que suas ideias proporcionam uma perspectiva única e, ao mesmo tempo, atualizamos seu programa de pesquisa.

Palavras-chave: Debate sobre o cálculo socialista, agência, empreendedorismo, assimetria da informação. 


\section{Introduction}

ESG - Environment, Social, and Governance - is supposed to steer firms towards stewardship in the three systems in which they operate, the natural, the social, and their internal governance. Environment denotes the natural ecosystem in which the firms are integrated and their impact on, for example, the cryosphere, biodiversity, or climate. Social refers to the societal and cultural system with which the firms are involved, for example, their relationship to workers and indigenous peoples and their impact on social equality and mobility. Governance looks at the firms' internal systems, operations, and governance - for example, board representation, responsibilities, remuneration policies, or ways to manage conflicts.

Having recently emerged as a "mainstream" topic in economic and managerial theories and practices, ESG still is a little-understood area. From a perspective based on the Austrian School of Economics, it is an exciting topic, since it seems to pose a dilemma: on the one hand, it claims to empower individual actors; on the other, it aims to direct market processes to impose market outcomes. How, then, to evaluate ESG within the framework of the Austrian School?

This paper attempts to solve this dilemma by differentiating between the prima facie promise of ESG and its consequences. To do so, the Austrian conceptions of entrepreneurship, agency, and information asymmetry will be applied to evaluate it. This paper suggests that ESG poses a special "calculation problem" case within the socialist calculation debate. In the first section, this paper explains the current state of ESG in academic research and practice. In the second, it discusses the tools of Austrian Economics being used here, by contrasting them to similar concepts used in "mainstream" economics. The third section evaluates the dilemma of ESG differentiating between a prima facie and an "all things considered" view. Finally, the paper concludes by cautioning practitioners and academics about the promises of ESG, but hints at how it could be pursued in an Austrian agenda.

This paper makes a twofold contribution to the contemporary economic and managerial discussion. First, it is an economic assessment of ESG, deepening the understanding of this still emergent area. Second, it employs Austrian Economics in a new way, addressing contemporary issues. It shows its continuing relevance, roughly 150 years after its inception, in explaining and understanding economic phenomena. This paper also expands the research program of Austrian Economics.

\section{Esg - The State Of The Art}

There are at least three dimensions to an overview of ESG. The first is what it encompasses; the second is how it is done; and the third is how it relates to and differentiates itself from similar concepts, such as Corporate Social Responsibility (CSR) and sustainability.

There is no single list of ESG goals, and its concepts often overlap. This being said, efforts are being made to develop a common understanding of ESG to integrate it into investment, business, and operational decisions. Often, this common understanding is built via inclusionary lists. The "E" captures energy efficiency, carbon footprint, greenhouse gas 
emissions, deforestation, biodiversity, climate change, pollution mitigation, waste management, and water usage. The "S" covers labor standards, wages and benefits, workplace and board diversity, racial justice, pay equity, human rights, talent management, community relations, privacy and data protection, health and safety, supply-chain management, and other human capital and social justice issues. The " $\mathrm{G}$ " covers the governance of the " $\mathrm{E}$ " and the " $\mathrm{S}$ " categories, but also the leadership over the business model, strategy, and operations. It includes corporate board composition and structure, strategic sustainability oversight and compliance, executive compensation, political contributions and lobbying, bribery and corruption. It primarily encompasses the long-term and short-term business decisions, steering them to set and achieve goals (compare with Hill (2020)).

Beyond this approach by-inclusion, there are also attempts to conceptualize ESG. Its core idea is to include the stewardship of an economic actor's natural, social and inner governance systems into his actions, aligning them towards a goal in which internal contradictions are minimized or, ideally, inexistent. The economic actor can be a firm, an entrepreneur, an investor, an intermediary, or a pooled resource. This abstract idea does not say which specific goal ESG follows or how it is implemented. In this regard, approaches can roughly be clustered in three different groups: some argue that ESG should create synergies with business models (QUERISH et al. 2021), others view it as a goal per se of the agent's action (LANDI; SCIARELLI, 2019), and yet others consider it to be a constraint (COQUERET, 2021). The synergy view maintains that, if fully integrated into a business model, ESG factors lead to superior performance, creating new business opportunities, new products, and new markets, with fewer costs. With this additional stream of cash flow, ESG-firms increase their profits or value. The per se view posits that, whether ESG improves an actor's business is less important than being a good steward of nature, society, and its internal systems. Even if the actor underperforms economically, this deficit is compensated by the superior stewardship in all other, possibly not measurable, aspects. The constraint view incorporates ESG into business models as a set of additional rules, and its associated costs are similar to, for example, laws and cultural norms. According to this third view, ESG is just a constraint, a source of costs that might only mitigate risks in the best-case scenario.

These divergences to explain the exact goals of ESG, or how to implement it, affect the methodologies and measurements applied. Contemporarily, categorizing an action as ESG largely depends on the actor's perspective. For example, some pressure groups consider all financial investments in commodities futures non-ESG; CAIA, the Chartered Alternative Investment Analyst Association, considers investments in liquid commodity futures ESGcompliant (CHAMBERS et al. 2020). Another example is the discussion about whom to include in boards of directors and whether the choice of a person should rely primarily on his/her achievements and potential or his/her contribution to diversity (FERNANDEZ-TEMPRANO, 2020; TEJERINA-GAITE, 2020). The dependence of the definition on the individual actor, and the self-assessment it includes, leads to considerable variance in ESG. While, in principle, there is no argument against variation, it is a problem for ESG itself, since its third component, G, is usually understood to entail comparison and benchmarking. If, however, ESG is agentdependent, comparisons are difficult and benchmarking, impossible. On a more operational 
level, ESG-methodologies being developed (see below) seek to create a basis for intersubjective comparison. However, as long as the views on ESG remain unclear, or even contrarian, its methodologies will remain opaque, preventing actors from identifying and separating its empirical effects. Reviewing ESG, Cornell (2020, p. 61) highlights the conceptual questions at hand:

The claim here is that the enthusiasm for ESG investing has been exaggerated for three reasons. First, it is not clear what constitutes an ESG investment in the context of a complex, integrated economy. Second, the impact on investment performance of a preference for ESG investments has not been sufficiently recognized outside academic circles. Finally, many leading practitioners have stated that the importance of ESG considerations implies that the corporate objective of maximizing shareholder value, which lies at the core of much of finance theory, is outdated and needs to be replaced by a more comprehensive stakeholder model. The conclusion is that the benefits of the traditional model and the dangers of a broader stakeholder model have not been adequately appreciated.

Unsurprisingly, the methodology used to apply and assess ESG faces many challenges. Far from any harmonization, methodology and measurement diverge and keep diverging, as Kotsantonis and Serafeim (2019) explain in four cumulative insights:

1. The sheer variety, and inconsistency, of the data and measures, and of how companies report them. Listing more than 20 different ways companies report their employee health and safety data, the authors show how such inconsistencies lead to significantly different results when looking at the same group of companies.

2. 'Benchmarking,' or how data providers define companies' peer groups, can be crucial in determining the performance ranking of a company. The lack of transparency among data providers about peer group components and observed ranges for ESG metrics creates market-wide inconsistencies and undermines their reliability.

3. The differences in the imputation methods used by ESG researchers and analysts to deal with vast 'data gaps' that span ranges of companies and time periods for different ESG metrics can cause large 'disagreements' among the providers, with different gap-filling approaches leading to big discrepancies.

4. The disagreements among ESG data providers are not only large, but actually increase with the quantity of publicly available information. Citing a recent study showing that companies that provide more ESG disclosure tend to have more variation in their ESG ratings, the authors interpret this finding as clear evidence of the need for a clearer understanding of what different ESG metrics might tell us and how they might best be institutionalized for assessing corporate performance.

The striking differences and contrarieties found in contemporary empirical studies about ESG can best be understood as mirroring the opacity and frictions among views and methodologies. For example, in a detailed study, Verheyden et al. (2016) point at ESG empirically strengthening returns and lowering risk. Similarly, Aw et al. (2017) find that companies and investors with robust, qualitative ESG-processes outperform those without them. However, if ESG is decomposed into different factors, no single ESG factor seems to outperform the factors of entrepreneurship, innovation, or shareholder value (CORNELL, 2021). Dimson et 
al. (2020, p. 85) pushes it further: "In the authors' opinion, isolated ESG ratings are unlikely to make a material contribution to portfolio returns."

One possible reason for the disparity of views, contents, and results on ESG is its relative recentness. Neither the academic world nor the practitioners had time to study and apply it to its full extent. Therefore, there is a lack of consolidation. Another possible reason contributing to the conceptual quagmire is the recent surge of similarly fuzzy approaches in the last decade. Like ESG, there are sustainability and Corporate Social Responsibility (CSR), for example.

CSR is a self-regulating business model that helps a firm being socially accountable to itself, its stakeholders, and the public. By practicing corporate social responsibility, also called corporate citizenship, firms become conscious of their impact on all aspects of society, including economic, social, and environmental. In 2010, the International Organization for Standardization (ISO) released a set of voluntary standards meant to help firms implement corporate social responsibility. Unlike other ISO standards, ISO 26000 provides guidance, rather than requirements, because the nature of CSR is more qualitative than quantitative, so its standards cannot be certified. Therefore, CSR is even more dependent than ESG on the self-description and self-assessment of the economic actor. Possibly, ESG's self-assessment line comes from the older CSR. But, unlike ESG, there is little attempt to compare or benchmark actors regarding their CSR (AGUDELO et al. 2019).

Sustainability refers to the synergy created by combining economic, ecological, and social aspects in a long-term view. At the same time, it is a much more precise and demanding concept than ESG. Unlike ESG, it cannot be interpreted as a constraint, a correction, or an improvement of a business model. Sustainability's necessary condition is the synergy of all its components. Synergy goes beyond producing beneficial outcomes; it demands that these outcomes are, at the same time, beneficial to all three dimensions, and mutually dependent. Often, sustainability is discussed or implemented via the United Nation's Sustainable Development Goals. They are a possible - but not the only - way to operationalize sustainability. They are also criticized for compromising operationalization, being full of political tradeoffs, and not (fully) abiding by the demands of synergy (HANSMANN, 2012; PEDERCINI et al. 2019).

How could we summarize ESG? It is the combination of stewardship on ecological, social, and internal governance systems by economic actors. What these aspects entail, and how to combine them is controversial. Consequentially, whether ESG has a beneficial impact on businesses or its components is difficult to assess, because of the lack of a consistent and coherent conception and methodologies for its implementation. In comparison to similar concepts, ESG goes beyond CSR. It does not seem to pursue sustainability.

\section{The ToolBox of Austrian Economics}

Focusing on some analytical concepts of Austrian Economics, this section prepares these "tools" to be applied in analyzing ESG. It involves explaining the concepts, or "tools," comparing them with similar theories in contemporary "mainstream" economics. While 
doing so, they are slightly updated to fit the contemporary discussion. This section focuses on entrepreneurship, agency, and information asymmetry.

"Mainstream" economics is generally concerned with efficiency and analytical laws. "Efficiency" refers to the ratio of input to output or the means-ends calculations made by the economic actor. The tradeoffs involved are the result of using analytical models to calculate these input-output-rations. "Mainstream" economics conceives action as the quantifiable outcome of a system of equations. But, Austrian economics does not neglect efficiency or means-end calculations. However, these are paired with a concern for effectiveness or the capability to produce a desired result, usually imagined or envisaged before an action occurs. While Austrian Economics also subscribes to the law-likeliness of economic agents, the lawlike conditions are usually derived logically and have a possibilistic - not a measurable, statistic probabilism - nature. For the Austrian School, the agent will not buy something at a price $p$, because $p$ equals an equilibrium condition; he does so if the market price is lower than his individual valuation of this good. He can still decide otherwise, if new information arises, or institutional conditions change. Institutions are framework-conditions but also rules, culture, and similar influencing factors (see several chapters in Kirzner (1982)). This brief characterization helps understand how the Austrian conception goes beyond the "mainstream" in the following theories.

Entrepreneurship is the first concept to be discussed in this section. "Mainstream" economics has great difficulty in fitting it into its theory, and for a long time, its model remained "entrepreneurless" (BYLUND, 2015). Even in those theories with an entrepreneur, he is considered nothing more than an optimizing actor, i.e., an abstract entity operating along the lines of law-like maximizations and constraints derived by equations (TEECE; KAY, 2019). On the other hand, Austrian Economics considers entrepreneurship central to economic activity. While not sharing a universal definition of entrepreneurship, a common denominator suggests entrepreneurship is a calculated, temporal bet. It is a bet because he cannot guarantee the success of a business model. As an act of creating or exploring perceived opportunities, the entrepreneur accepts the uncertainty of the business model fitting (or creating, or revolutionizing) consumer's wishes. It is a temporal bet because he devises in the present a business model that might succeed in creating cash flows in the future. It is also a temporal bet because time passes between setting up the business model, producing the goods, and making them available to the consumer. Along the way, conditions, constraints, preferences, market processes also change. On the one hand, this is a risk since the entrepreneur needs to react to these changes. On the other, it is an additional opportunity for him to learn and incorporate them into his business model. Finally, it is a calculated bet because the entrepreneur calculates the cost of production against a personal assessment of the benefit generated by the business model, against a subjective valuation. This, too, presents risks and opportunities. There is the distinct risk of costs changing, but also that the entrepreneur's valuation does not match the evaluations of other participants to the market processes, especially consumers.

On the other, the entrepreneurial calculation is dynamic, allowing the entrepreneur to react to price changes and valuations. In Austrian Economics, entrepreneurship is central to 
the creative economic activity itself. However, it is also multi-faceted: the entrepreneur seeks to increase efficiency via calculation and find effectiveness in a successful business model. On the one hand, entrepreneurial activity follows logical patterns, trading off present and future valuations; on the other, the entrepreneur acts upon the institutional changes, adapting the business model (GUNNING, 2018; FOSS; KLEIN; 2002).

The second concept to consider is agency. It refers to aligning the interests and actions of actors in an explicit or implicit contractual relationship in which there is one actor, the agent, acting on behalf of another, the principal. As Mitnick (2015) puts it, agency has two sides: the activities and problems of identifying and providing services (agent side), and the activities and problems of guiding and correcting agent actions (principal side). Because all actions and corrections have costs, it often does not pay off for the principal (or the agent) to insist on or provide perfect agency. For example, shareholders of corporations are principals. They own the organization and wish for, say, the long-term flourishing of the firm. They, as principals, decide to trust the operational decision-making of managers or agents. Ideally, these managers share the interest of the shareholders, matching their actions to it. However, given the managers' proximity to operations - in terms of knowledge and time -, they have an advantage over the principals. In externalizing decision-making and action, the principals remove or distance themselves from leadership and exchange information within and outside the firm. This position incentivizes agents to pursue their own aims, such as increasing their quarterly bonus payment, enhancing their reputation, or taking on leadership themselves - even at the expense of the firm or its principals. So, it is the institutional arrangement between agents and principals that determines the strength of the agents' incentives to do so, or that stipulates the countermeasures the principals take to mitigate these incentives (refer to Eisenhardt (1989) for a lucid introduction and assessment from a Neoclassic perspective).

The Austrian analysis of agency is somewhat different. Based on Mises' exploration of the socialist calculation (1920; 1935; 1936; 1949), he applies private ownership and property rights to address two problems: economic calculation, and incentives. For him, private ownership and property rights are fundamental for performing economic calculation. First, they price the costs of means of production and processes; second, they align the evaluation of benefits to the subjective valuation of the entrepreneur. For Mises, the entrepreneur is the owner, or principal, unless otherwise informed. He recognizes the importance of private ownership and property rights to the problem of incentives within organizations, and the relationships among these topics.

In the socialist calculation debate, Mises is debunking different arguments on the feasibility of socialism. For instance, Lange declares that, if the arrangement of incentives is right, a manager in a socialist system would be able to achieve the same outcomes as a manager in a capitalist system. For Mises, this is not possible, because, in socialism, there is no pricing mechanism that allows the socialist manager to calculate. However, leaving this aside, Mises also recognizes an even deeper problem: the socialist manager. Without using the concepts of principal and agent, Mises frames agency via private ownership, separating the propertybearing owner or entrepreneur from the typically property-less manager. Even if managers 
were to participate in the firm's profit, they remain property-less and, therefore, do not have to endure all the consequences of their decisions and actions. Letting them participate in the profits while keeping them property-less incentivizes courses of action with high upward potential, sharing the results with management, but also high downward potential, which results are borne by the owners alone. Consequentially, Mises discourages such an approach, since it creates perverse incentives, or, as he puts it, "encourages a lack of seriousness (MISES, 1936, p. 191):

It is just useless to attempt to solve the problem by new methods of remuneration. It is thought that if the managers of public enterprises were better paid, competition for these posts would arise and make it possible to select the best men. Many go even further and believe that the difficulties will be overcome by granting managers a share in the profits. (...) But the problem is not nearly so much the question of the manager's share in the profit, as of his share in the losses that arise through his business conduct. Except in a purely moral sense, the property-less manager of a public undertaking can be made answerable only for a comparatively small part of the losses. To make a man materially interested in profits and hardly concerned in losses simply encourages a lack of seriousness.

Here, Mises differentiates between public and private enterprises. Managers in private enterprises "are either already owners of a not inconsiderable fraction of the share capital, or hope to become so in due course (MISES, 1920; 1935, p. 36)." Then, these managers seem bound up with the interests of the business they administer because, as property owners, they themselves "must feel the loss arising from unwisely conducted business (ibid, 40)." However, the rights on residual income streams are not enough to align managers' interests with those of the owners. Mises contends that residual control rights are important in analyzing managers. Even if they have residual control rights, their primary incentive is to use them to their own benefit and to the detriment of the firm: their knowledge of the firm gives them an advantage over all the other bearers of control rights. Managers run operations, having more knowledge about the corporation and a timely advantage over other bearers of control. So, managers are still incentivized to pursue their own agenda, even in public companies with private management. After all, they keep a larger portion of profits but share the losses within the firm's structure.

Note how the Austrian analysis of agency goes beyond the "mainstream". While the latter sees it as a form of overall-inefficient behavior, the former frames it as the effective pursue of chances enabled by institutional asymmetries, in ownership structure. Also, "mainstream" argues that agency is a failure of the market to produce information, while Austrians suggest it to be a property mismatch.

Let us take a closer look at the asymmetry of information, the third and final concept of this article. In "mainstream" economics, asymmetric information is a condition under which an actor possesses more information than the other. One actor's access to more relevant and up-to-date information can result in business imbalances. Just like with other goods and services, information adds value. In "mainstream" economics, if participants in a market have imperfect information, but everyone is equally uninformed, imperfect information does not 
lead to market failure because every actor is equally off. If, however, one actor knows more than others and acts on this knowledge, then the market fails, i.e., it cannot produce the most efficient outcome (HILLIER, 1997). Austrian Economics, however, has a different take. DiLorenzo (2011) is adamant about it:

The notion that so-called asymmetric information is a source of market failure is deeply flawed. Asymmetric information is essentially a synonym for "the division of knowledge (and labor) in society," which is the whole basis for trade and exchange and the success of markets. Moreover, the real asymmetric information problem is with the government, since all taxpayers are rationally ignorant of almost everything the government does. Asymmetric information is, therefore, a source of government failure, not market failure.

Instead of looking at conditions to maximize efficiency in general equilibrium, Austrian Economics includes effectiveness conditions, treating markets as processes in which actors create, transform, and exchange goods and information, among other things. Market processes imply content, valuation, and use differentiation. For the producer, the cup of coffee is a means to make a profit; for the consumer, it is a means to drink coffee, stay awake, or feel more comfortable. The producer sells the cup above cost; the consumer buys it if its price is below or equal to his consumer's subjective valuation. Similarly, information is exchanged, and its content, price, and use depend on the actors involved in this particular exchange. To do the right thing respecting their individual perspectives, each actor needs differentiated public and nonpublic information. Besides, actors increase the content of information available with each action, adding dynamics to the exchange, thus increasing opportunities. In this view, information is highly divided, decentralized, and subjective. Instead of being a framework condition to increase efficiency, it is part of the individual actor's subjective means-end calculations and their calculated, temporal bets. Actors can adapt to new information as well as learn in the market processes.

However, there is space for information asymmetries in Austrian Economics, which is occupied by the institutions accompanying market processes. As DiLorenzo argues, nonmarket-actors do not participate in market processes and therefore have no access to its feedback mechanism. Non-market actors such as governments have no way of knowing what individual actors want or do; neither can state actors know anything relevant about goods, prices, valuations, and so on. Nonetheless, if these agents impose their views on markets, we have a government failure. Yet, there are also governance failures: even in market processes, there are sub-processes in which usual market mechanisms are not used, for example, in the delegated management of firms. While managers are paid, their decisions seldom result from negotiations in price, information, or quantity. Instead, consist of hierarchical plans, organizational disposition, or non-market bargains. Since there is no market process in the managerial organization of work, managers have less information than markets would allow them to attain. But managers have a different type of information, which is one about the operations of the firm. This is not shared with any other group of actors, nor is it accessible through market processes, creating a mismatch that can be called a failure. Note: the absence of market mechanisms allows these asymmetries to arise. Besides, since there is no market 
mechanism to correct or diffuse information, the asymmetry persists. This governance problem comes from the firm's institutional setup if it uses non-market mechanisms in decision-making. In the case of the entrepreneur managing the firm, the asymmetry of information is mitigated by the market-prone entrepreneur-owner.

Coming full circle, this section introduced and slightly updated three instruments in the "toolbox" of Austrian Economics: entrepreneurship, agency, and information asymmetry. Besides worrying about efficiency, Austrian Economics also analyzes effectiveness; instead of the equation of law-likeliness with an analytical model, Austrians look for logical laws, allowing for possibilism. In conclusion, Austrian Economics takes institutions more seriously than the "mainstream" does.

\section{Applying Austrian Analysis to ESG}

In section 1, the conception of ESG has been criticized for its inconsistency and incoherence. This section analyzes ESG from a perspective broadly situated in Austrian Economics using the theories discussed in section 2. In addition to the problems identified above, we will show that ESG creates perverse incentives in agency due to asymmetric information in governance. Instead of relying on entrepreneurship to find effective courses of action, it exacerbates the principal-agent problem by focusing on an overanalytical idea of efficiency. This section integrates the topics discussed in the two previous ones.

As reviewed in section 1, ESG is not unambiguous. It involves different elements which have to be weighed and traded off against each other. Often, these aspects involve judgment calls reflecting normative preferences. In a public company, it is difficult to find this balance between the shareholders' preferences. Any tradeoff here will be at the expense of the welfare of some shareholders. Here, ESG proponents can argue that this is already the case in almost all decisions concerning a public corporation. While this is true, it also acknowledges that there are tradeoffs that potentially harm some shareholders. Then, it seems illogical to add to this problem by introducing yet another tradeoff with the harmful potential. Again, ESG proponents argue that the shareholders harmed are incentivized to sell their stakes in the firm. However, this argument only holds from the point of view of efficiency: shareholders interested in mitigating the harm done to them leave the firm. From the point of view of effectiveness, it does not. Shareholders became part-owners of the firm due to different factors, such as their quest for profits, belief in the firms' business models, and need for diversification. Negating these goals by considering the shareholder's decision only in terms of minimizing harm leaves many important, even determinative factors of economic decision-making out of scope. Maybe, the shareholder is willing to endure harm due to his belief in the success of the firm's business model. Just because he is willing to do so does not mean that harm is legitimized. Additionally, diminishing shareholders' welfare, i.e., harming and threatening them until they leave the firm, is hardly a recipe for a long-term and free economic system; in fact, it is a kind of expropriation, which, in turn, disincentives entrepreneurship. Finally, even from an intra-ESG perspective, it is highly questionable. The social and governance aspects of 
ESG are supposed to be inclusive, i.e., engaging with diverse points of view. Decisions made contrary to some, or arguably all shareholders' interests or actions that prompt them to leave the firm are not inclusive.

In most firms, however, ESG is delegated to managers. In this case, they trade off the different aspects of ESG, and have incentives to maximize their expected benefits, even to the detriment of the firm. In contemporary settings, managers benefit personally from "increasing" the ESG rating of a firm. They can benefit from what they consider as reputation, contacts in the media, increased market value, or, where applicable, bigger bonus payments. Potentially, their personal benefit is achieved at the cost to the firm. The firm pays for ESG programs, consultants, and ratings; if there are any losses from the integration of ESG, the firm absorbs them; if ESG requires business operations to be shut down or products to be canceled, again, is at the expense of the firm. Naturally, if ESG succeeds by diminishing risk exposures or increasing profits, the firm benefits. However, note how costs and benefits are unevenly distributed. In any case, the manager benefits: whether ESG has caused harm or benefits, he claims to have implemented it. However, the firm only benefits in the upward case; in the downward, it bears all the costs, including the salary of managers. The situation is skewed positively for the manager and negatively for the firm. This is especially the case under the per se view, i.e., a necessary activity to the firm, even if detrimental to its economic interests. In this case, with a grain of salt, managers would not even need to care about economic outcomes, since good ESG legitimizes any outcome.

ESG proponents can argue that the firm can create incentives to align managers' actions with shareholders' interests. Some methods include making managers accountable for outcomes, requiring them to be transparent about which actions they have taken and why, or distributing bonuses in case of successful implementation. These methods are currently being deployed, but they entail acknowledging ESG's intrinsic agency problem. More importantly, these methods do not address the fundamental mismatch among the positive and negative skew of managers' actions and their impacts on the firm; they might even exacerbate them. Manager accountability incentivizes managers to do more than they need to have "proof of work." Transparency requirements incentivize managers to adapt the information they disclose to suit their interests (remember information asymmetry). Furthermore, tying bonuses with meeting ESG-goals incentivizes managers to increase the costs of ESG they bear on the firm to secure their bonus. "Mainstream" economics acknowledges the problem of agency and tries to remedy it by increasing governance density. In turn, Austrian Economics sees it as a governance failure. Increasing the density of non-market rules in a firm, such as reporting, measuring against a non-price benchmark, and relying on planning, exacerbates agency problems. This is also true in ESG.

This agency problem does not arise only within firms, but extends to the relationship among them. To increase their ESG ratings, ESG requires some firms to impose their ESG on others. For example, a corporation producing material goods needs to convince its suppliers to subscribe to ESG to show an ESG-compliant supply chain. In another example, a pension fund might divest from steel producers, given their impact on the environment, or toy producers, 
given their impact on society. This is a particular form of the agency problem, because it relies on the managers of one firm influencing the entrepreneurs or managers of another. In this case, the managers of the first firm do not have residual income, residual rights, or even the informational advantage over any principal or agent in the target firm. But, if they have sufficient market power, they can impose their view of ESG on the target firm. The former gains the "ESG premium" on its actions while imposing its views and costs on the latter. ESG proponents argued that it is about actively engaging with as many economic agents as possible, and that engagement involves a dialogue with partners incorporating their views. Engagement, however, is only one way of doing ESG; other and more widely used approaches are positive and negative screening. In the case of positive screening, the ESG-firm will actively search for ESG compliant partners; in negative screening, the ESG-firm disassociates from non-ESG compliant partners. In both cases, the partners' point of view is not taken into account. In these standard cases, ESG incentivizes firms to use their market power, which is, paradoxically, inconsistent with ESG itself. Note the economics involved; here, the target firm has more market-prone information about itself than the first firm acting on ESG. Still, the actor with less information behaves as having more information about the target firm. This mismatch becomes even stronger when an ESG-firm makes its partners anticipate ESG, even in the absence of market signals or prices, based solely on normativity and speculation. As the calculation debate tells us, it is impossible to correctly anticipate a risk if no pricing signals refer to it. Finally, additional problems materialize when ESG is imposed on others. If their communications occur via their respective shareholders, the objection-based harm explained in the first part of this section applies; if, however, it occurs via managers, the objection based on agency discussed prior to this section applies.

In the contemporary discussion about ESG, there is hope that a standardized methodology would enhance processes related to its trading off aspects, implementing it, and measuring it. The problem is not the lack of standardization or even comparability. Instead, it leaves two elements out of scope. First, methodologies relate to goals. As seen in the previous section, the goals of ESG diverge fundamentally: either it is a new opportunity for the firm, a constraint, or an activity per se. Methodologies depend on this definition of goals; if they diverge, methodologies will diverge and contrast each other. Second, externalizing methodology comes together with specific agency problems - the ESG developer methodology versus the firm - and specific asymmetries of information - the ESG developer relying on non-marketinformation. If, however, ESG methodologies are developed with market instruments, there is a significant probability that, in the end, profit-maximization will emerge as the adequate one. Researching this topic, Fama (2021) posits:

Observed contract structures are competitive solutions to the problem of maximizing stakeholder welfare when contracting is costly. Winning contract structures typically set fixed payoffs for most stakeholders, with residual risk borne by shareholders, who then get most of the decision rights. With rising interest in environmental, social, and governance (ESG) issues, there is sentiment for replacing the max shareholder wealth decision rule with max shareholder welfare. This view does not recognize that investors view max welfare in 
terms of their overall consumption-investment portfolios. Since firms are not privy to the total ESG exposures of shareholders, max shareholder wealth is the appropriate decision rule.

Finally, current approaches to ESG are entrepreneurless. By understanding economic activity primarily as an exercise in efficiency, ESG focuses on incorporating its desiderata either as constraints, per se legitimized activities, or as return enhancers. In doing so, current approaches to ESG miss arguably its most important lever: entrepreneurial discovery. Many entrepreneurs are developing and pursuing business cases addressing social and/or environmental issues. The results of these business cases are not shown in or measurable by ESG ratings because they often escape its nomenclature. For example, a firm developing an app that makes it more accessible for people to invest and track their assets contributes to the Social similar to a firm that implements vocational education. An entrepreneur reducing waste or transforming material waste into thermal energy acts Environmental as another firm installing double or triple-layered windows to diminish the energy loss of a building. The firm substituting external managers by members of the entrepreneurial family increases Governance, as another firm implementing intra-operational pricing. However, all these examples escape contemporary attempts at measuring and implementing ESG, because they fixate on formulating conditions under which a firm can be categorized ESG instead of focusing on the locus of the entrepreneurial activity, at what the firm does.

Using instruments broadly located within Austrian Economics, this section analyzed five problems of ESG. First, it diminishes the welfare of the owners of firms; second, it creates agency problems and information asymmetries between the owners of the firm and its managers; third, it expands these problems to the interaction among firms; fourth, by delegating methodologies to ESG-service providers, its lack of conceptional cohesion and coherence is exacerbated; finally, it remains entrepeneurless.

\section{Conclusion}

In the introduction of this paper, we mentioned the dilemma of ESG: on the one hand, it claims to empower individual actors; on the other, it aims to command market processes and impose market outcomes. What seemed counterintuitive at the beginning of the study becomes explainable at the end. ESG maintains that it empowers individual actors to engage in environmentally, socially, and governance-wise valuable activity. This claim, however, is only prima facie. It is a promise that ESG cannot keep. All things considered, ESG cannot do it because it does not incorporate the most crucial aspect of economic activity, which is entrepreneurship. Instead, it focuses on the optimization of conditions under which economic activity can occur. As it is currently treated, ESG aspires to direct market processes and dictate their outcomes. This is a two-pronged mistake. First, contemporary ESG incurs all the problems of the calculation debate. Second, it claims to be of economic relevance: although it is difficult to imagine how, considering its disregard for what entrepreneurs and other economic agents actually do.

In the course of this paper, we exposed other problems of ESG. Independently from the Austrian analysis used here, ESG was shown to be opaque, with at least three different and 
contrarian approaches: one frames ESG as an opportunity, the other as a constraint, and the third as a constraint per se activity. From a slightly modified Austrian perspective, ESG is is discussed as leading to several types of agency prand asymmetries of information. In discussing these shortcomings, this paper, however, also hints at how it can work: via entrepreneurship. A meaningful ESG should, then, be willing to acknowledge what entrepreneurs do, the effectiveness of their goals, as well as their individual means-ends-calculations. In such a way, ESG could deliver its emancipatory promise. But it needs to renounce its methodologies, and especially its attempt at directing market processes and dictating market outcomes.

\section{References}

AGUDELO; Mauricio; ANDRÉS, Latapí. Jóhannsdóttir, Lára; Davídsdóttir, Brynhildur. A literature review of the history and evolution of corporate social responsibility. International Journal of Corporate Social Responsibility, v. 4, n. 1, p. 1-23, 2019.

AW, Edward et al. A Morality Tale of ESG: Assessing Socially Responsible Investing. The Journal of Wealth Management, v. 19, n. 4, p. 14-23, 2017.

BYLUND, Per L. The Problem of Production: A new theory of the firm. London: Routledge, 2015.

CHAMBERS, Donald R.; Kazemi, Hossein B.; Black, Keith H. Alternative Investments: CAIA level II. Hoboken: John Wiley \& Sons, 2020.

COQUERET, Guillaume. Perspectives in ESG equity investing. Published by SSRN on March 10, 2021. Available at: https://ssrn.com/abstract=3715753. Accessed on: Jul 192021.

CORNELL, Bradford. ESG Investing: Conceptual Issues. The Journal of Wealth Management, v. 23, n. 3, p. 61-69, 2020.

CORNELL, Bradford. ESG preferences, risk and return. European Financial Management, v. 27, n. 1, p. 12-19, 2021.

DIMSON, Elroy; Marsh Paul; Staunton Mike. Divergent ESG Ratings. The Journal of Portfolio Management, v. 47, n. 1, p. 75-87, 2020.

DILORENZO, Thomas. A Note on the Canard of "Asymmetric Information" as a source or Market Failure. The Quarterly Journal of Austrian Economics, v. 14, n. 2, 2011.

EISENHARDT, Kathleen M. Agency theory: An assessment and review. Academy of Management Review, v. 14, n. 1, 1989.

FAMA, Eugene F. Contract costs, stakeholder capitalism, and ESG. European Financial Management, v. 27, n. 2, 2021.

FERNÁNDEZ-TEMPRANO, Miguel A.; TEJERINA-GAITE, Fernando. Types of director, board diversity and firm performance. Corporate Governance: The International Journal of Business in Society, v. 20, n. 2, 2020.

FOSS, Nicolai J.; KLEIN, Peter G. (eds.). Entrepreneurship and the Firm: Austrian Perspectives on Economic Organization. Chettelham: Edward Elgar Publishing, 2002.

GUNNING, J. Patrick. The Theory of Entrepreneurship in Austrian Economics. London: Routledge, 2018. 
HANSMANN, Ralph; MIEG, Harald A.; FRISCHKNECHT, Peter. Principal sustainability components: empirical analysis of synergies between the three pillars of sustainability. International Journal of Sustainable Development \& World Ecology, v. 19, n. 5, 2012.

HILL, John. Environmental, Social, and Governance (ESG) Investing: A Balanced Review of Theoretical Backgrounds and Practical Implications. London: Academic Press, 2020.

HILLIER, Brian. The Economics of Asymmetric Information. New York: Macmillan International Higher Education, 1997.

KIRZNER, Israel M. (ed.) Method, Process, and Austrian Economics. Lexington: Lexington Books, 1982.

KOTSANTONIS, Sakis; SERAFEIM, George. Four Things No One Will Tell You About ESG Data. Journal of Applied Corporate Finance, v. 31, n. 2, p. 50-58, 2019.

LANDI, Giovanni; SCIARELLI, Mauro. Towards a more ethical market: the impact of ESG rating on corporate financial performance. Social Responsibility Journal, v. 15, n. 1, p. 11-27, 2019.

MISES, Ludwig von. Economic Calculation in the Socialist Commonwealth. In Friedrich A. Hayek, ed. Collectivist Planning. Auburn: The Ludwig von Mises Institute, [1920/1935] 1990.

MISES, Ludwig von. Socialism. Indianapolis: Liberty Classics, [1936] 1981.

MISES, Ludwig von. Bureaucracy. Grove City: Libertarian Press, [1944] 1983.

MISES, Ludwig von. Human Action: A Treatise on Economics. Auburn: The Ludwig von Mises Institute, [1949] 1998.

MITNICK, Barry M. Agency Theory. Wiley Encyclopedia of Management, v. 2, p. 1-6, 2015.

PEDERCINI, Matteo et al. Harvesting synergy from sustainable development goal interactions. Proceedings of the National Academy of Sciences, v. 116, n. 46, 2019.

QURESHI, Muhammad et al. Do ESG Endeavors Assist Firms in Achieving Superior Financial Performance? A Case of 100 Best Corporate Citizens. SAGE Open, v. 11, n. 2, p. 1-18, 2021.

TEECE, David J.; KAY, Neil. The evolution of the theory of the firm. Chattelham: Edward Elgar Publishing, 2019.

VERHEYDEN, Tim; ECLES, Robert G.; FEINER, Andreas. ESG for all? The impact of ESG screening on return, risk,and diversification. Journal of Applied Corporate Finance, v. 28, n. 2, 2016.

RECEBIDO 07 DE AGOSTO 2021. APROVADO: 20 DE OUTUBRO 2021. 